International Journal of Life Sciences
Available online at http://sciencescholar.us/journal/index.php/ijls
Vol. 3 No. 1, April 2019, pages: $12 \sim 24$
e-ISSN: 2550-6986, p-ISSN: 2550-6994
https://doi.org/10.29332/ijls.v3n1.241

\title{
Immersion Effect with Extracts of Papaya Leaf, Pineapple, Ginger on Quality of Organoleptic and Bali Beef Nutrition
}

\begin{abstract}
CrossMark
\&cictorupdates
I Ketut Sukada a, I Wayan Suberata ${ }^{\text {b }}$, Ni Made Artiningsih Rasna ${ }^{c}$

Article history: Received 18 July 2018, Accepted: 31 December 2018, Published: 17 January 2019

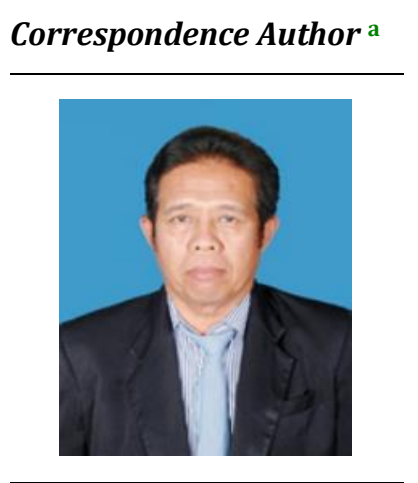

Keywords

Bali beef;

organoleptic;

papaya;

raw implants;

water binding capacity;

Abstract

This research was conducted at the Laboratory of Animal Produce Technology Faculty of Veterinary, Udayana University. Aims to determine the effect of papaya leaf extract, extract pineapple and ginger extract on the physical and organoleptic qualities of Bali beef through soaking. Variables measured to determine the physical properties of meat between meat $\mathrm{pH}$ and shrinkage of cooked meat, while the variables measured to determine the organoleptic quality of Bali beef among other examples: color, texture, taste, and smell of meat by panelist. The analyze used variance analysis, while experiment design used in this research is, Completely Random Design simple 4 treatment pattern 5 replication from Steel and Torie processed by Costas Statistic Method. Measurement of $\mathrm{pH}$ of the meat using $\mathrm{pH}$ meters, and the measurement of moisture content after cooking, is sought through the calculation of the percentage ratio of the difference between the weight of raw meat and the weight of meat after cooking. Conclusions and results of this study found that beef soaked in pineapple extracts showed: raw shrinkage, texture, color, taste, tenderness, and odor showed the best physical and organoleptic quality ( $\mathrm{P}$ $<0.05$ ) compared to ginger extract and papaya leaf extract. While the physical and organoleptic qualities of beef soaked in extra papaya leaves show the worst indication.
\end{abstract}

e-ISSN: 2550-6986, p-ISSN: 2550-6994C Copyright 2019. The Author. SS Journals Published by Universidad Técnica de Manabí. This is an open-access article under the CC BY-SA 4.0 license (https://creativecommons.org/licenses/by-sa/4.0/) All rights reserved.

a Faculty of Veterinary, Universitas Udayana, Denpasar, Indonesia

b Faculty of Veterinary, Universitas Udayana, Denpasar, Indonesia

c Faculty of Veterinary, Universitas Udayana, Denpasar, Indonesia 


\section{Contents}

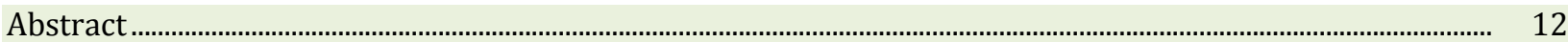

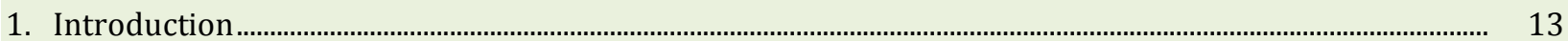

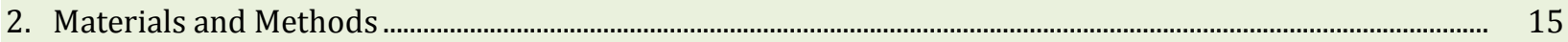

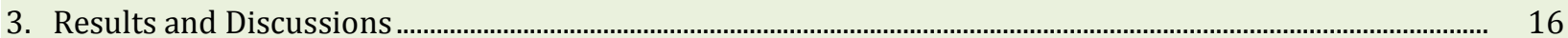

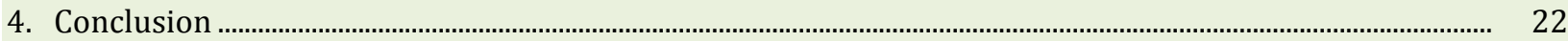

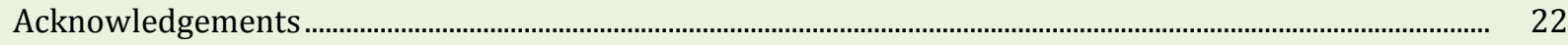

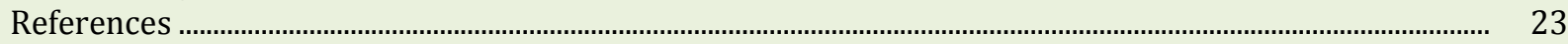

Biography of Authors ............................................................................................................................................. 24

\section{Introduction}

The spread of the image that Bali beef is less competitive with imported cattle, is actually a very ironic thing because in fact, Bali beef, especially on the island of Bali, is very popular with Balinese people. The Bali government has recently carried out a policy of promoting Bali beef to hotels in Bali to be better known by tourists nationally and internationally. Today, it is predicted that only $15 \%$ of Bali beef is consumed by guests in hotels in Bali. Balinese beef is sold fresh because usually after being slaughtered directly sold to the market, this is different from imported beef that comes frozen. Carcass characteristics of Bali cattle classified as ideal beef cattle in Indonesia because they have a compact and harmonious body shape (Masudana, 1990). In addition to Bali beef, it is also known as Kobe Japanese wagyu meat which is widely consumed by foreign tourists in Bali. The level of preference of foreign tourists in Bali for the two types of meat is very different, tourists prefer wagyu meat when compared to Bali beef (Suwiti et al., 2013). This was due to differences in maintenance management, where wagyu was cut at a young age (6 months) while Bali cattle cut for meat production generally reached 4-5 years. The genetic difference between Bali and wagyu cattle can affect the quality of meat, the differences between the two cows can affect physical properties such as water holding capacity, $\mathrm{pH}$, and cooking losses. Especially for the needs of housewives in Bali, it seems that it still needs a solution to make Bali beef so that when cooked it can be faster to soften. Some experiences gained from housewives who became consumers of Bali beef stated that when cooking Bali beef requires a little time to boil to reach tender, therefore they tried to make efforts to overcome these obstacles by giving treatment to meat cows before being cooked, namely: first wrapped with papaya leaves, soaked with pineapple extract or soaked with ginger extract. The effort to soften the meat before cooking certainly has its own novelty to improve the quality of Bali beef from an effective angle and the speed of cooking to achieve softness. To find out an effective and efficient way to cook Bali beef, the authors are interested in conducting research on: "The effect of immersion in papaya leaf extract, pineapple fruit extract and ginger extract on the physical and organoleptic qualities of Bali beef.

Special Purpose and Benefits Specific Objectives of this Research are: (1). To determine the effect of soaking Bali beef in papaya leaf extract, pineapple extract and ginger extract on the physical and organoleptic qualities of Bali beef. (2) Looking for the effect of the best extract between pineapple, ginger, and papaya leaves on Bali beef before being cooked to become tender faster.

Benefits: Benefits of this study: (1) Can reduce the negative image stating that beef is tough and difficult to cook (2) Increasing the economic value of Bali beef competing in national and international markets. (3) Giving confidence to domestic and international tourists to get to know more closely that Bali beef is not much different from other beef in the world.

Urgency (virtue) The urgency of this study is: Urgency This research is divided into two types: (1) Urgency in terms of technology, this research is expected to be able to provide an effective solution in the strategy of cooking Balinese beef to make it soft faster. Effective strategies can indirectly increase the economic value of the quality of Bali beef nationally and internationally (2) Urgency in scientific terms. This research is expected to increase scientific value especially in the field of Statistics and Research Methodology, in accordance with the task of the writer as a lecturer in Statistics and Research Methodology in the Faculty of Animal Husbandry, Udayana University. (3) The urgency in terms of research output. This research is expected to produce published scientific papers in accredited national and international journals that have the opportunity to produce a patent.

Sukada, I. K., Suberata, I. W., \& Rasna, N. M. A. (2019). Immersion effect with extracts of papaya leaf, pineapple, ginger on quality of organoleptic and Bali beef nutrition. International Journal of Life Sciences, 3(1), 12-24. https://doi.org/10.29332/ijls.v3n1.241 
Chapter II Literature review Meat is a food source of animal protein that is favored by all levels of society because of its delicious taste and high nutritional value. Meat is one of the livestock products that are almost inseparable from human life. Meat can cause satisfaction or pleasure for those who eat it because of its complete nutritional content so that the nutritional balance for life can be fulfilled. Soeparno (2009) defines meat as all animal tissues and all products produced by tissue processing are suitable for eating and do not cause health problems for those who eat them. The physical quality of meat includes $\mathrm{pH}$, water binding capacity, cooking shrinkage and texture. The physical quality of meat is affected by the process before and after cutting. Pre-cutting factors that can affect meat quality are genetic, species, nation, type of livestock, sex, age, feed including additives (hormones, antibiotics, and minerals) and stressful conditions. After factor cuts that affect the quality of meat include meat $\mathrm{pH}$, methods of storage, types of meat muscles and location of meat muscles (Soeparno, 2005). Organoleptic properties of fresh meat are important aspects to be considered. This is related to the consideration of consumers in choosing meat. Usually, consumers will more easily choose meat through physical appearance which includes color, texture, brightness, and flavor intensity of fresh meat. According to Soeparno (2009), the appearance of meat is much influenced by factors during maintenance, handling before cutting to handling after cutting. Characteristics of a muscle have a close relationship with its function, because of its function, the amount of connective tissue differs between muscles. This connective tissue is related to meaty meat. Furthermore, Lawrie (2003) suggests that differences in meat protein levels can be caused by differences in structure and level of muscle activity. With the different types of muscles, there is a difference in nitrogen distribution so that different levels of muscle activity can produce different levels of meat protein. Physical properties play an important role in the processing process due to the physical properties that determine the quality and types of process to be made. Physical properties are strongly influenced by factors before cutting and after cutting. An important factor before cutting is resting behavior that can determine stress levels in livestock. According to Aberle et al., (2001) \& Sriyani et al., (2018), non-rested livestock will produce meat that is dark, hard-textured, dry, has a high $\mathrm{pH}$ value and high water binding power. An important factor after the decision that influences the quality of meat is a sailor. Withering meat will affect the tenderness, flavor, and binding power of the water. These factors are closely related to postmortem time or the time after cutting. The process of glycolysis after livestock is cut off has an effect on the $\mathrm{pH}$ value. The longer postmortem time will decrease the lower the $\mathrm{pH}$ due to the process of converting muscle to meat at a certain postmortem time. The ultimate $\mathrm{pH}$ value of normal meat ranges from 5.4-5.8 at 6 hours postmortem and the color of the meat will become bright red (Aberle et al., 2001). According to Lawrie (2003), the $\mathrm{pH}$ of the meat can decrease rapidly to reach 5.4-5.5 for several hours after cutting. The standard $\mathrm{pH}$ of healthy animal meat and enough fresh cut is 7-7.2 and will continue to decline for 24 hours. The decrease in $\mathrm{pH}$ is not the same for all tendons of an animal and among animals is also different. Postmortem $\mathrm{pH}$ values will be determined by the amount of lactic acid produced from glycogen during the process of anaerobic glycolysis. The $\mathrm{pH}$ value will be lower in stressed animals before cutting and will produce pale, soft and runny meat (pale, soft, exudative = PSE). Purnomo \& Adiono (1985) added that the formation of lactic acid causes a decrease in the $\mathrm{pH}$ of the meat and causes damage to the structure of muscle protein and the damage depends on temperature and low $\mathrm{pH}$. After the animals are cut, the supply of muscle oxygen stops, thus the supply of oxygen is no longer in the muscle and the rest of the metabolism cannot be removed from the muscle, so the meat will experience a decrease in $\mathrm{pH}$. Some meat quality characteristics that are important in testing and influencing consumer attractiveness are $\mathrm{pH}$, water holding capacity, color and tenderness (Purbowati et al., 2006). Water holding capacity is the ability of the meat to retain water content during external treatment such as cutting, heating, grinding and processing. The size of the water holding capacity affects the color, tenderness, elasticity, impression of juice, and meat texture (Suardana \& Swacita, 2009).

The binding capacity of meat is strongly influenced by $\mathrm{pH}$, species, age and muscle function as well as feed, transportation, the temperature or humidity, storage, sex, health, pre-cutting treatment and intramuscular fat (Soeparno, 2005). PH value is one of the criteria in determining the quality of beef. The $\mathrm{pH}$ value of meat in live cattle is around 7.0-7.2 (neutral $\mathrm{pH}$ ). The decrease in $\mathrm{pH}$ value will occur after cattle are slaughtered (post-mortem), namely when the heart stops pumping blood, so that muscle tissue and other tissues do not get blood supply. Factors that influence the $\mathrm{pH}$ of the meat include stress before cutting, hormone/drug injection, species, individual livestock, and muscle types, electrical stimulation, enzyme activity, and the occurrence of glycolysis, softening of collagen while cooking temperature more influences myofibrillar 
toughness (Dwiloka et al., 2006). The amount of cooking shrinkage can be affected by the amount of damage to the cellular membrane, the amount of water coming out of the meat, the shelf life of the meat, degradation of the protein, and the ability of meat to bind water (Shanks et al., 2002). Cooking shrinkage is an indicator of the value of meat nutrition associated with meat content, namely the amount of water that is bound in and between muscles. Low water binding capacity will result in high cooking shrinkage values. Water Holding Capacity (WHC) is strongly influenced by the $\mathrm{pH}$ value of meat, according to Soeparno (2005) if the pH value is higher or lower than the isoelectric point of meat (5.0-5.1) then the cooking shrinkage value of the meat will be low. Bali and Wagyu beef have different organoleptic test values because there are differences from cattle breeds so that they provide different levels of preference. The difference in breeds may affect the physical characteristics of meat such as the water binding capacity (DIA), acidity ( $\mathrm{pH}$ ), and cooking loss of meat. The cooking loss is a function of temperature and cooking time (Hartono et al., 2013). Length of cooking time effects.

\section{Materials and Methods}

Material The research material consisted of male Bali beef who had been aged around 4 years obtained at the Super Market around the Denpasar area. Research material as a treatment the research used several types of extract ingredients as ingredients for soaking Bali beef before cooking. The ingredients are made from three extracts of traditional ingredients, namely papaya, pineapple and ginger leaves which are purchased around Denpasar Kumbasari Market.

Research Equipment and Research Support Facilities

Research Support Tools and Facilities are:

a) Meat cutting knife

b) PH Meter Meat

c) Digital Scales.

d) Pot/pot to boil 3 pieces of meat with a volume of 2 liters

e) Cooling Cupboard

f) Stoneware to boil meat.

g) LPG-fueled Gas Stoves.

h) The container where the meat will be tested is as much as the number of panelists

i) Place of meat sample to be tested in the laboratory

\section{Length of Research}

The research started from April 2018, took 8 weeks, starting from collecting materials and materials and research materials to preparing proposals, making reports and conducting the final seminar of the study.

\section{Procedure for Research Implementation}

The procedure for carrying out this research was carried out from the procurement of materials and the manufacture of research sample treatments, among others:

1) Balinese beef is divided into 4 parts according to the number of research treatments. The meat is cut into $2 \mathrm{~cm} 2$ cubes, then weighed and soaked in papaya leaf extract, pineapple extract, and ginger extract. Each sample is given a treatment code, then the storage is carried out in the cooling cabinet for 30 minutes.

2) After 30 minutes the meat is removed from the cupboard, the $\mathrm{pH}$ is measured again, then washed with water and then drained until there is no more water to soak the meat. After finishing recording, each sample is boiled in water for a few minutes at 810C until cooked/cooked. Then the meat sample is drained and cooled until there is no visible water content then weighed to get the weight of the meat after boiling. Samples of cooked meat were then carried out by organoleptic tests using 10 panelist. Each panelist is given an explanation and notes about the score of the use of organoleptic values. Furthermore, physical quality values and organoleptic quality were recorded and tabulated.

Sukada, I. K., Suberata, I. W., \& Rasna, N. M. A. (2019). Immersion effect with extracts of papaya leaf, pineapple, ginger on quality of organoleptic and Bali beef nutrition. International Journal of Life Sciences, 3(1), 12-24.

https://doi.org/10.29332/ijls.v3n1.241 


\section{Results and Discussions}

\subsection{Bali Beef Physical Characteristics}

a) Cooked shrinkage is defined cooking loss as fluid loss or weight loss after cooking. Cooking shrinkage is an indicator of meat nutritional value associated with meat juice levels, namely the amount of water that is bound in nature and between muscle fibers (Soeparno, 2009). Lawrie (2003) states that meat is of good quality, the cooking shrinkage value is smaller than that of low-quality meat. Bouton et al., (1971) in Soeparno (2009) say that cooking losses can be influenced by $\mathrm{pH}$, length of sarcoma of muscle fibers, length of cut of muscle fibers, contraction status of the myofibril, size of sample weight of meat and cross section of meat. As the cooking temperature increases and/or the cooking time is longer, the liquid meat is lost until it reaches a constant level (Soeparno, 2009). Cooking losses will decrease linearly with increasing age of livestock. The differences in the nation's livestock, weight and feed consumption can also cause differences in cooking losses. This difference occurs because of differences in the amount of meat fat and fat deposition. Cooking shrinkage values vary between $1.5 \%-54.5 \%$ with a range of $15 \%-35 \%$ (Romans \& Ziegler, 1974 in Syam, 2009).

b) The degree of Acidity $(\mathrm{pH})$ The degree of acidity $(\mathrm{pH})$ shows the relative acidity of freedom of substance (Bacus, 1984). The pH of fresh meat ranges from 5.3 - 6.0 and depends on the cost of muscle glycogen at the time of cutting. PH values associated with WHC values, ie at high pHs have high WHC values (Buckle et al., 1983). According to Lawrie (2003), the $\mathrm{pH}$ value is used to indicate the level of acidity and basicity of a substance. The $\mathrm{pH}$ value is an important indicator of meat quality by taking into account the quality of technology and the influence of quality of fresh meat. Observation of $\mathrm{pH}$ is important because the $\mathrm{pH}$ changes affect the quality of meat produced (Sudrajat, 2007). pH changes affect the quality of meat produced (Sudrajat, 2007).

c) Color Score Color can also be used as an indicator of freshness or maturity. Whether or not the method of mixing or processing can be characterized by the presence of 11 uniform and even colors (Winarno, 2004). The color of the cooked meat is generally gray, the color change is caused by globin denaturation and Maillard reaction. According to (Lawrie, 2003), apart from being caused by pigments, the color changes in cooked meat are also due to globin denaturation and are affected by caramelization of carbohydrates and Maillard reaction between reducing sugars and amino acids. Myoglobin is the main pigment of meat and its concentration will affect the intensity of red meat. The difference in hemoglobin levels causes differences in the intensity of the meat color. Determinants of meat color are influenced by feed, species, nation, age, sex, stress (level of activity and type of muscle).

\subsection{Organoleptic properties Meat}

Organoleptic properties Meat has organoleptic properties which can be related to five basic properties, namely taste (taste), smell (smell), appearance/color (sight), smoothness (feel) and hardness. The four basic tastes identified from meat are salty, sour, sweet and bitter (Abustam \& Ali, 2004). Organoleptic testing is a test based on the sensory process. Sensing is defined as a physio-psychological process, which is the awareness or introduction of the senses to the properties of objects because of the stimuli that the sensory devices receive from the object. Sensing can also mean a mental reaction (sensation) if the sensory device gets stimulus (stimulus). The organoleptic test is a test of the properties of food ingredients that are carried out using taste, smell, sight and touch sensing devices. The test is a preference test (hedonic test) which includes taste, aroma, color, texture, and tenderness (Soeparno, 2009).

a) Aroma is one of the parameters of organoleptic assessment of a product. One that can affect the aroma of cooked meat is the cooking temperature (Soeparno, 2009). In general, the smell that is received by the nose and brain is a variety of ingredients or a mixture of four main ingredients namely fragrant, sour, rancid and charred (Winarno, 2004). 
b) Taste Feeling ranked first on consumer acceptance, the taste of a food ingredient is influenced by several factors, namely chemical compounds, temperature, consistency, and interaction with other flavor components and the type and duration of cooking.

c) The texture is sensing that is connected by touch or touch. Characteristics that are often used as references are violence, cohesiveness and water content (de Man, 1997). The beef texture is largely determined by the water content, fat content, and type of carbohydrate.

d) Tenderness According to Soeparno (2009) that tenderness can be determined subjectively and objectively. Overall tenderness impression includes three aspects. First, the ease of early penetration of teeth into the flesh, second, the ease with which the meat is chewed into smaller pieces and third, the amount of residue left after chewing is done is a preference test (hedonic test) which includes taste, aroma, color, texture and tenderness (Soeparno, 2009).

\subsection{Organoleptic Quality}

Organoleptic quality of beef Bali valued panelist that has been determined. In this study, the organoleptic parameters that will be observed are color, texture, and taste and the test of preference that will be carried out by 10 panelists. Previous panelists were trained first to know the organoleptic properties to be tested. The assessment using the organoleptic quality scale test was assessed by the test scale of numbers 1 to 5 . Panalis who had understood the criteria for the organoleptic scale to be tested were each given an assessment label. Panalis assesses by giving a cross mark on the selected value label that they think is appropriate. Samples of Bali beef that are ready to be assessed are presented in each container according to the treatment planned in the study. The cooking loss of meat is the proportion of the weight of meat lost during cooking or heating. Cooking shrinkage is one indicator of the value of meat nutrition associated with the binding capacity and moisture content. The average cooking shrinkage of Balinese beef soaked in extracts of ginger, pineapple, papaya and without extract, before cooking is shown in Table 1.

Table 1

Average Balinese shrimp cooking shredded meat soaked in ginger extract, pineapple, and papaya and without extract for 60 minutes

\begin{tabular}{ccccc}
\hline No & Without Extract & Extract Pineapple & Extract Ginger & Extract Papaya \\
\hline 1 & 45.6923 & 28.8776 & 30.8602 & 33.7838 \\
2 & 45.0769 & 29.0816 & 31.0753 & 36.4865 \\
3 & 42.4615 & 29.1837 & 29.6774 & 32.4324 \\
4 & 43.3846 & 27.3469 & 29.7849 & 35.1351 \\
5 & 42.9231 & 29.2857 & 30.5376 & 33.7838 \\
$\mathbf{X}$ & $\mathbf{4 3 . 9 0 7 7}$ & $\mathbf{2 8 . 7 5 5 1}$ & $\mathbf{3 0 . 3 8 7 1}$ & $\mathbf{3 4 . 3 2 4 3}$ \\
SD & $\mathbf{\pm 1 . 4 0 4 1 4 c}$ & $\mathbf{\pm 0 . 8 0 1 5 2 a}$ & $\mathbf{\pm 0 . 6 2 9 7 4 a}$ & $\mathbf{\mathbf { 1 1 . 5 4 0 7 8 b }}$ \\
\hline
\end{tabular}

The results of this study indicate that Bali beef soaked in extracts of pineapple, ginger, papaya and without extracts ranged from 28.7551 to $43.9077 \%$, Bali beef showed very real water cooking rate was lower (P $<0.05)$ than Bali beef without soaked in the extract. Balinese beef muscle soaked in pineapple, ginger and papaya extract shows more inflated indications so that it is softer or more tender. Balinese beef with the lowest cooking shrinkage value was shown sequentially by meat soaked in pineapple extract, ginger extract, and papaya extract, while Bali beef without extract showed the largest cooking shrinkage. According to Syam (2009), cooking shrinkage values vary between $1.5 \%-54.5 \%$ with a range of $15 \%-35 \%$. Table 5.1 .1 shows the difference in cooking shrinkage percentage of meat in soaking meat in different extracts. Meat which was soaked in pineapple extract a showed the lowest cooking shrinkage while meat with soaking in papaya leaf extract and without extract showed the highest cooking shrinkage.

Sukada, I. K., Suberata, I. W., \& Rasna, N. M. A. (2019). Immersion effect with extracts of papaya leaf, pineapple, ginger on quality of organoleptic and Bali beef nutrition. International Journal of Life Sciences, 3(1), 12-24.

https://doi.org/10.29332/ijls.v3n1.241 
a) The level of acidity $(\mathrm{pH})$ of meat

The level of acidity $(\mathrm{pH})$ is one indicator of the quality of meat. The good acidity of beef is 5.1 - 6.1 because it is more stable against damage by microbes, while beef which is alkaline will allow higher microbial growth.

Table 2

Average $\mathrm{pH}$ of Balinese beef soaked in the extract, Ginger, Pineapple Extract, Papaya Extract, and No Extract, for 60 minutes

\begin{tabular}{ccccc}
\hline No & Without Extract & Extract Pineapple & Extract Ginger & Extract Papaya \\
\hline 1 & 5.5 & 3.6 & 4.8 & 4.6 \\
2 & 5.6 & 3.6 & 4.7 & 4.6 \\
3 & 5.5 & 3.7 & 4.7 & 4.5 \\
4 & 5.7 & 3.5 & 4.8 & 4.5 \\
5 & 5.6 & 3.6 & 4.8 & 4.6 \\
$\mathbf{X}$ & $\mathbf{5 . 5 8}$ & $\mathbf{3 . 6}$ & $\mathbf{4 . 7 6}$ & $\mathbf{4 . 5 6}$ \\
SD & $\mathbf{\mathbf { 0 . 0 8 3 6 a }}$ & $\mathbf{\pm 0 . 0 7 0 7 d}$ & $\mathbf{\pm 0 . 0 5 4 7 b}$ & $\mathbf{\pm 0 . 0 5 4 7 c}$ \\
\hline
\end{tabular}

The results of this study indicate that the $\mathrm{pH}$ of meat soaked in extracts of pineapple, ginger, papaya and without extract has a $\mathrm{pH}$ ranging from 3.6 to 5.8, indicating that the $\mathrm{pH}$ of Bali beef is resistant and stable against bacterial attacks because according to Tanaka et al., (2002) \& Lawrie (2003), the pH of meat above 6 new will show that meat is not resistant to bacterial attack. Balinese beef soaked in extracts, pineapple, ginger, and papaya indeed shows the $\mathrm{pH}$ of the meat tends to be more acidic than the meat soaked without extract, this shows that the meat without soaking in pineapple, ginger and papaya extract shows an indicator that meat is damaged faster because it is susceptible to attack bacteria.

b) Meat Color Score

Observation of meat color in this study refers to the standard color of meat according to SNI 3932: 2008 which has a score of one to nine. The color score is determined based on the characteristics of the appearance of the color of the meat.

Table 3

The average score of Balinese beef soaked in ginger, pineapple, papaya and without extract for 60 minutes

\begin{tabular}{lllll}
\hline No & Without Extract & Extract Pineapple & Extract Ginger & Extract Papaya \\
\hline 1 & 9 & 8 & 7 & 8 \\
2 & 8 & 7 & 7 & 8 \\
3 & 9 & 8 & 7 & 9 \\
4 & 8 & 3 & 8 & 9 \\
5 & 7 & 8 & 7 & 8 \\
6 & 5 & 4 & 7 & 7 \\
7 & 9 & 7 & 9 & 9 \\
8 & 8 & 7 & 9 & 9 \\
9 & 8 & 7 & 3 & 9 \\
10 & 4 & 5 & 7 & 8 \\
11 & 7 & 4 & 8 & 6 \\
12 & 5 & 4 & 6 & 7 \\
13 & 9 & 7 & 7 & 8 \\
14 & 9 & 8 & 7 & 9 \\
15 & 9 & 5 & 8 & 7 \\
Total & $\mathbf{1 1 4 , 0 0}$ & $\mathbf{9 2 , 0 0}$ & $\mathbf{1 0 7 , 0 0}$ & $\mathbf{1 2 1 , 0 0}$ \\
$\mathbf{X}$ & $\mathbf{7 , 6 0 \pm 1 , 6 8 b}$ & $\mathbf{6 , 1 3} \pm \mathbf{1 , 7 7 a}$ & $\mathbf{7 , 1 3 \pm 1 , 4 1} \mathbf{a b}$ & $\mathbf{8 , 0 7 \pm 0 , 9 6 b}$ \\
\hline
\end{tabular}


The results of statistical analysis showed that the color of Balinese beef soaked in Ginger Extract, Pineapple, Without Extracts and Papaya was significantly different $(\mathrm{P}<0.05)$ of Balinese beef in this study (Table.1.3) Balinese beef soaked in papaya leaf extract shows the darkest color with a score of $8.07 \pm 0.96$ (dark red), beef without deep red extract with a score of $7.60 \pm 1.68$ (dark red), Bali beef soaked in red Ginger extract with score of $7.13 \pm 1.41$ (red), Bali beef soaked in pineapple extract bright red with a color score of $6.13 \pm 1.77$ (bright red). According to Lawrie (2003), the color of beef is bright red because the meat is considered to be of good quality when compared to dark red meat, the difference in color in the meat is due to differences in acidity and basicity of the extract used for soaking before the beef is cooked.

In general, the aroma received by the nose and brain is more a variety of ingredients or a mixture of four main ingredients, namely fragrant, sour, rancid and charred (Winarno, 2004). Fragrance or odor is a parameter of organoleptic quality of meat. The average aroma score of Balinese beef soaked in the ginger extract, pineapple, without papaya extract and the extract is presented in Table 4

\subsection{The Organoleptic Characteristics of Bali Beef}

a) Scent of Meat

Table 4

Scouring value of Balinese beef flavor soaked in Ginger Extract, Pineapple, Without Papaya Leaf Extract and Extract soaked for 60 minutes from 20 panelist which are housewives who have been determined

\begin{tabular}{ccccc}
\hline No & Without Extract & Extract Pineapple & Extract Ginger & Extract Papaya \\
\hline 1 & 4 & 3 & 4 & 5 \\
2 & 4 & 4 & 3 & 5 \\
3 & 4 & 4 & 3 & 5 \\
4 & 3 & 3 & 4 & 4 \\
5 & 4 & 3 & 3 & 5 \\
6 & 4 & 3 & 3 & 5 \\
7 & 4 & 3 & 4 & 5 \\
8 & 4 & 3 & 4 & 4 \\
9 & 4 & 3 & 3 & 5 \\
10 & 3 & 3 & 3 & 4 \\
11 & 4 & 3 & 4 & 5 \\
12 & 4 & 4 & 3 & 5 \\
13 & 4 & 4 & 3 & 5 \\
14 & 3 & 3 & 4 & 4 \\
15 & 4 & 3 & 3 & 5 \\
16 & 4 & 3 & 3 & 5 \\
17 & 4 & 3 & 4 & 5 \\
18 & 4 & 3 & 4 & 5 \\
19 & 4 & 3 & 3 & 4 \\
20 & 3 & 3 & 3 & 5 \\
\hline
\end{tabular}

Rank Correlation (Kendal Tau and Spearman)

Variable 1: Without Extract (control)

\begin{tabular}{|l|c|c|c|c|c|c|}
\hline Variable 2 & $\mathrm{N}$ & Kendal Tau & $\mathrm{P}$ & Spearman $\mathrm{r}$ & $\mathrm{p}$ & \\
\hline Pineapple & 20 & 0,25 & $0,123 \mathrm{~ns}$ & 0,6390 & 0,0024 & $* *$ \\
\hline Ginger & 20 & $-0,102$ & $1 \mathrm{~ns}$ & 0,338 & 0,1445 & $\mathrm{Ns}$ \\
\hline Papaya & 20 & 0,76 & $0,000^{* * *}$ & & 0,0000 & $* * *$ \\
\hline
\end{tabular}

Sukada, I. K., Suberata, I. W., \& Rasna, N. M. A. (2019). Immersion effect with extracts of papaya leaf, pineapple, ginger on quality of organoleptic and Bali beef nutrition. International Journal of Life Sciences, 3(1), 12-24. https://doi.org/10.29332/ijls.v3n1.241 
Information:

$\mathrm{n}$ : number of samples 1

p: value

r: Spearman's ranking coefficient

ns: insignificant

***: very significant

The results of non-metric analysis of Kendal Tau and Spearman found that the meat soaked in the aroma of pineapple extract was most preferably r: $0.639(\mathrm{P}<0.05)$ while the meat soaked in ginger extract did not show a significant difference $r$ : $0.338(\mathrm{p}>0,05)$, and meat soaked in extinct papaya significantly gives a pungent odor that panelist doesn't like, r: $0.846(\mathrm{P}<0.05)$. From this study, it was found that the aroma of Bali beef soaked in pineapple extract is most preferred because the aroma is slightly fragrant, then the meat soaked with papaya leaves is not liked by panelist because of its strong aroma and a slightly bitter taste while the extracts meat is also less preferred because of its smell rather fishy.

The texture is sensing that is connected by touch or touch. Characteristics that are often used as references are violence, cohesiveness, and water content. Beef textures are highly determined by the water content, fat content, and type of carbohydrate. Texture score of Balinese beef soaked in Ginger Extract, Pineapple, without Papaya leaf extract and extract presented in Table 5.

Table 5

Texture score of Balinese beef marinated in Ginger Extract, Pineapple, without papaya leaf extract and extract soaked for 60 minutes

\begin{tabular}{ccccc}
\hline No & Without Extract & Extract Pineapple & Extract Ginger & Extract Papaya \\
\hline 1 & 4 & 3 & 4 & 5 \\
2 & 4 & 3 & 3 & 5 \\
3 & 4 & 4 & 3 & 5 \\
4 & 3 & 3 & 4 & 4 \\
5 & 4 & 3 & 3 & 5 \\
6 & 4 & 3 & 3 & 4 \\
7 & 3 & 3 & 3 & 5 \\
8 & 4 & 3 & 4 & 4 \\
9 & 4 & 3 & 3 & 5 \\
10 & 3 & 3 & 3 & 4 \\
1 & 4 & 3 & 4 & 5 \\
2 & 4 & 3 & 3 & 5 \\
3 & 4 & 4 & 3 & 5 \\
4 & 3 & 3 & 4 & 4 \\
5 & 4 & 3 & 3 & 5 \\
6 & 4 & 3 & 3 & 4 \\
7 & 3 & 3 & 3 & 5 \\
8 & 4 & 3 & 4 & 4 \\
9 & 4 & 3 & 3 & 5 \\
10 & 3 & 3 & 3 & 4
\end{tabular}

Rank Correlation (Kendal Tau \& Spearman) Variable 1: Without Extract (control)

\begin{tabular}{|l|l|l|l|l|l|l|}
\hline Variable 2 & $\mathrm{N}$ & Kendal Tau & $\mathrm{P}$ & Spearman $\mathrm{r}$ & $\mathrm{P}$ & \\
\hline Pineapple & 20 & 0,218 & $0,186 \mathrm{~ns}$ & 0,639 & 0,0024 & $*$ \\
\hline Ginger & 20 & $-0,047$ & $1 \mathrm{~ns}$ & 0,338 & 0,1445 & Ns \\
\hline Papaya & 20 & 0,358 & $0,028^{*}$ & 0,563 & 0,0096 & $* *$ \\
\hline
\end{tabular}


Description:

$\mathrm{n}$ : number of samples

p: value

r: Spearman rank coefficient

ns: nonsignificant

***: very significant

The texture of Bali beef soaked in extracts ranged from 3.1 to 4.6. The results showed Bali beef soaked in pineapple extract showed the softest significant results $r$ : $0.639(\mathrm{P}<0.05)$, while meat soaked in the ginger extract was not significantly different and the meat soaked in papaya extract showed a rather significant result rough $\mathrm{r}: 0,563(\mathrm{p}<0,05)$.

b) Taste

Taste is sensing that is connected to taste. The taste score of Balinese beef soaked in Ginger Extract, Pineapple, Papaya Extract, and Without Extract before being included in Table 6

Table 6

Taste scores of Balinese beef marinated in Ginger Extract, Pineapple, Papaya Extract, and No Extract soaked for 60 minutes

\begin{tabular}{ccccc}
\hline No & Without Extract & Extract Pineapple & Extract Ginger & Extract Papaya \\
\hline 1 & 4 & 4 & 4 & 5 \\
2 & 4 & 3 & 4 & 5 \\
3 & 4 & 3 & 3 & 5 \\
4 & 4 & 3 & 3 & 5 \\
5 & 4 & 4 & 3 & 5 \\
6 & 4 & 3 & 3 & 5 \\
7 & 4 & 3 & 3 & 5 \\
8 & 4 & 4 & 4 & 4 \\
9 & 3 & 3 & 4 & 4 \\
10 & 3 & 3 & 3 & 5 \\
11 & 4 & 4 & 4 & 5 \\
12 & 4 & 3 & 4 & 5 \\
13 & 4 & 3 & 3 & 5 \\
14 & 4 & 3 & 3 & 5 \\
15 & 4 & 4 & 3 & 5 \\
16 & 4 & 3 & 3 & 5 \\
17 & 4 & 3 & 3 & 5 \\
18 & 4 & 4 & 4 & 4 \\
19 & 3 & 3 & 4 & 5 \\
20 & 3 & 3 & 3 & 4
\end{tabular}

Rank Correlation (Kendal Tau and Spearman)

Variable 1: Without Extract (control)

\begin{tabular}{|l|l|l|l|l|l|l|}
\hline Variable 2 & $\mathrm{N}$ & Kendal Tau & $\mathrm{P}$ & Spearman $\mathrm{r}$ & $\mathrm{P}$ & \\
\hline Pineapple & 20 & 0,327 & $0,0138^{*}$ & 0,6280 & $0,0033^{* * *}$ & ** \\
\hline Ginger & 20 & $-0,010$ & $1 \mathrm{~ns}$ & 0,3383 & $0,1445 \mathrm{~ns}$ & Ns \\
\hline Papaya & 20 & 0,028 & $0,0786 \mathrm{~ns}$ & 0,6278 & 0,0030 & ** \\
\hline
\end{tabular}

Description:

$\mathrm{n}$ : number of samples

Sukada, I. K., Suberata, I. W., \& Rasna, N. M. A. (2019). Immersion effect with extracts of papaya leaf, pineapple, ginger on quality of organoleptic and Bali beef nutrition. International Journal of Life Sciences, 3(1), $12-24$. https://doi.org/10.29332/ijls.v3n1.241 
p: value

r: Spearman rank coefficient

ns: nonsignificant

***: very significant

The taste of Bali beef soaked in pineapple extract was significantly favored by panelist $r: 0.6280(\mathrm{p}<0.05)$, while Bali beef soaked in ginger did not shows a significant difference, and Bali beef soaked in papaya extract is significantly less favored by panelist because of its bitter taste. R: $0.6278(p<0.05)$

\section{Conclusion}

Based on the results and discussion, it was concluded that Balinese beef soaked in the ginger extract, pineapple, papaya leaves and without different extracts had physical and organoleptic characteristics such as $\mathrm{pH}$, cooking loss, color, taste, and tenderness $(\mathrm{P}<0.05)$.

\section{Acknowledgments}

The author would like to thank Directorate General of Empowerment Research and Development, The Ministry of Technology Research and Higher Education the Republic of in February onesie for the fund through Rector and Institute for Research and Community Service Udayana University Contract Agreement with Featured Research Study Program, in February 2018. 
References

Aberle, H. B., \& Forrest, J. C. (2001). Principle of Meat Science, 4 th Edit. Kendal.

Abustam, E., \& Ali, H. M. (2004). Bahan Ajar Ilmu dan Teknologi Pengolahan Daging. Fakultas Peternakan. Universitas Hasanuddin, Makassar.

Bacus, J. (1984). Update: meat fermentation 1984. Food Technology (USA). http://agris.fao.org/agrissearch/search.do?recordID=US8530773

Bouton, P. E., HARRIS, P. T., \& Shorthose, W. R. (1971). Effect of ultimate pH upon the water-holding capacity and tenderness of mutton. Journal of food science, 36(3), 435-439. https://doi.org/10.1111/j.13652621.1971.tb06382.x

Buckle, K. A., Edwards, R. A., Fleet, G. H., \& Wootton, M. (1985). Ilmu Pangan. Terjemahan Hari Purnomo Adiono. Universitas Indonesia.

Buckle, K. A., Edwars, R. A., Flest, G. H., \& Wotton, M. Food Science. Hari Purnomo dan Adiono. 1985. Penterjemah Ilmu Pangan.

De Man, P., \& Warminski, A. (1997). Aesthetic ideology (Vol. 65). U of Minnesota Press.

Dwiloka, B., Rianto, E., \& Ekawati, R. (2006). Perbandingan Kualitas "Blade" Sapi Lokal dan Sapi Impor yang Diolah dengan Metode "Pan Frying". Jurnal Sains dan Teknolog I Hasil Ternak, 2(1), 8-22.

Hartono, E., Iriyanti, N., \& Santosa, R. (2013). Penggunaan pakan fungsional terhadap daya ikat air, susut masak, dan keempukan daging ayam broiler. Jurnal Ilmiah Peternakan, 1(1).

Lawrie, R. A. (2003). Ilmu Daging. Penerjemah Aminuddin Parakkasi.

Masudana, I. W. (1990, September). Pengembangan sapi Bali di Bali dalam sepuluh tahun terakhir(19801990). In Proceeding Seminar Nasional Sapi Bali. Denpasar (pp. 20-22).

Purbowati, E., Sutrisno, C. I., Baliarti, E., Budhi, S. P. S., \& Lestariana, W. (2006). Chemical composition of longissimus dorsi and biceps femoris on different slaughter weight of local male sheep reared in the village. Animal Production, 8(1). http://animalproduction.net/index.php/JAP/article/view/259

Romans, J. R., \& Ziegler, P. T. (1974). The Meat We Eat 10" edition. The interstate Printers and Publishers Inc., Danville, Illinois.

Shanks, B. C., Wulf, D. M., \& Maddock, R. J. (2002). The effect of freezing on Warner-Bratzler shear force values of beef longissimus steaks across several postmortem aging periods. Journal of Animal Science, 80(8), 2122-2125. https://doi.org/10.1093/ansci/80.8.2122

Sriyani, N. L. P., Suarta, I. G., Sumardani, N. L. G., Putri, B. R. T., \& Yupardi, W. S. (2018). Effect of carcass aging towards pork organoleptic quality of bali pig. International Journal of Life Sciences, 2(3), 136-141. https://doi.org/10.29332/ijls.v2n3.229

Suardana, I. W., \& Swacita, I. B. N. (2009). Higiene Makanan. Kajian Teori Dan Prinsip Dasar. Fakultas Kedokteran Hewan. Universitas Udayana, Denpasar.

Sudrajat, G. (2007). Sifat fisik dan organoleptik bakso daging sapi dan daging kerbau dengan penambahan karagenan dan khitosan.

Suparno, E. (2009). National Manpower Strategy (Strategi Ketenagakerjaan Nasional): Sebuah Upaya Meraih Keunggulan Kompetitif Global. Jakarta: Penerbit Buku Kompas.

Suparno, O., Covington, A. D., Phillips, P. S., \& Evans, C. S. (2005). An innovative new application for waste phenolic compounds: Use of Kraft lignin and naphthols in leather tanning. Resources, Conservation and Recycling, 45(2), 114-127. https://doi.org/10.1016/j.resconrec.2005.02.005

Suwiti, N. K., Suastika, P., Swacita, I. B. N., \& Piraksa, W. (2013, September). Tingkat kesukaan wisatawan asing di Bali terhadap daging sapi bali dan wagyu. In Proc Seminar Nasional Sapi Bali (Vol. 42).

Syam, S. S. (2002). A model and methodologies for the location problem with logistical components. Computers \& Operations Research,29(9), 1173-1193. https://doi.org/10.1016/S03050548(01)00023-5

Tanaka, J., Trianto, A., Musman, M., Issa, H. H., Ohtani, I. I., Ichiba, T., ... \& Scheuer, P. J. (2002). New polyoxygenated steroids exhibiting reversal of multidrug resistance from the gorgonian Isis hippuris. Tetrahedron, 58(32), 6259-6266. https://doi.org/10.1016/S0040-4020(02)00625-7

Winarno, F. G. (2004). Keamanan pangan jilid 1. M-Brio Press, Bogor.

Sukada, I. K., Suberata, I. W., \& Rasna, N. M. A. (2019). Immersion effect with extracts of papaya leaf, pineapple, ginger on quality of organoleptic and Bali beef nutrition. International Journal of Life Sciences, 3(1), 12-24.

https://doi.org/10.29332/ijls.v3n1.241 


\section{Biography of Authors}

\begin{tabular}{|c|c|}
\hline & $\begin{array}{l}\text { Dr. Ir. I Ketut Sukada, M.Si was born on May 21, 1957. He has four children, they } \\
\text { are Ni Luh Putu Mahasuari. SE. I Made Indra Pranayama. Ni Nyoman Reni } \\
\text { Maharani, S.Par. I Ketut Wiwaswan DananJaya, S.Ked. He lives in Jl. Segara Madia. } \\
\text { No. 2, Lingkungan Tanjung Benoa, Kelurahan Tanjung Benoa, Kecamatan Kuta } \\
\text { Selatan, Kabupaten Badung. He had finished his Bachelor of Academic at Faculty of } \\
\text { Animal Husbandry in the University of Udayana in 1982. He had completed his } \\
\text { Master Degree in the Institute of Bogor Agriculture in 1999. He had been reached } \\
\text { his Doctor Degree at Postgraduate of the University of Udayanan in } 2013 \text {. } \\
\text { Email: ketut_sukada888@yahoo.com }\end{array}$ \\
\hline & $\begin{array}{l}\text { I Wayan Suberata, S.Si., M.Si was born on May } 08 \text { 1967. He has three children, they } \\
\text { are I Gede Yudha Pradipta, S.Tr.Ak, I Made Yudhi Prayoga, I Komang Adi } \\
\text { Sastrawan. He lives in Jln. Pudak, Gg. Pudak Harum II/12, Batubulan, Kecamatan } \\
\text { Sukawati, Kabupaten Gianyar. He had finished his bachelor of academic at Faculty } \\
\text { of Mathematic and Natural Science in University of Udayana in 1993. He had } \\
\text { completed his master degree in Agricultural Biotechnology at University of } \\
\text { Udayana in } 2002 \\
\text { Email : yansubrata08@yahoo.co.id }\end{array}$ \\
\hline & $\begin{array}{l}\text { Ir. Ni Made Artiningsih Rasna, M.Si was born on December } 261954 \text {. She lives in } \\
\text { Jln. Gambuh Gang III No. } 1 \text { Denpasar. She has finished her bachelor of academic at } \\
\text { Faculty of Animal Husbandry in the University of Udayana in 1993. She had } \\
\text { completed her master degree in the institute of Bogor Agriculture in } 1996 . \\
\text { Email: artiningsihrasna@gmail.com }\end{array}$ \\
\hline
\end{tabular}

